Alla Rastrygina

https://doi.org/10.26881/pwe.2020.49.05

ORCID: 0000-0002-4393-2831

Central Ukrainian Volodymyr Vynnychenko

State Pedagogical University, Kropyvnytskyy, Ukraine

rastrygina.alla@gmail.com

\title{
Activation of a child's subjectivity in the upbringing space of free self-determination on the basis of pedagogy of freedom
}

\begin{abstract}
Summary
The article updates the problem of reconstruction of the modern upbringing process, the leading idea of which is the targeting of its goals, content, forms and methods at self-development of a child and the becoming of a child's subjectivity as an active, purposeful, initiative, creative and constructive position in his or her own livelihoods on the basis of humanistic values of a democratic society. The conceptual provisions of the author's concept of freedom pedagogy have become the starting point in solving the mentioned problem.

There have been defined the psychological and pedagogical conditions for the development of a child's subjectivity, the realization of which requires the establishing within the educational environment of an educational institution the upbringing space of free determination of a personality as a specially organized pedagogical environment, containing three basic components (spatial, socio-psychological and organizational-pedagogical) and provides opportunities for manifestation of initiative, volitional, creative, self-managerial forms of subjective activities of a personality. The basic approaches to the organization of the upbringing process on the basis of freedom pedagogy have been defined: pedagogy of indirect upbringing influence (directed freedom) and pedagogy of assistance (support).
\end{abstract}

Keywords: subjectivity, upbringing space of free self-determination, principles of pedagogy of freedom, components of pedagogical environment

Słowa kluczowe: podmiotowość, edukacyjna przestrzeń swobodnego samostanowienia, zasady pedagogiki wolności, elementy środowiska pedagogicznego

\section{Introduction}

The reforming of the national education system of Ukraine on the grounds of the new educational paradigm of the 21 st century updates the problem of reconstruction of the upbringing process, aimed at developing the subjectivity of a child on the basis of humanistic values of a democratic society. At the same time, the systematic implementation of humanistic models of upbringing is still a rather complicated process, which takes place against the background of the renewal of the national education system as a whole, and 
is accompanied by certain crisis phenomena, criticism of its current state, reformatory processes in pedagogical science and practice, intensive search for the new ways of upbringing and means of their implementation in real life. The active implementation of new upbringing models is hindered by both, the objective reasons related to the situation in the temporarily occupied territories in Eastern Ukraine and the Crimea, in which children and teachers have to exist now, and by the subjective ones, related to rejection of stereotypes in pedagogical consciousness and practical activities. The strong commitment to stereotypes is evidenced by the fact that while leading Ukrainian scholars and the entire progressive pedagogical community for almost thirty years now have been treating upbringing as a process of development of a child's personality, and on this basis they are developing the theory of modeling and constructing humanistic systems of upbringing (Bekh, Kievisas, Oleksyuk, Rastrygina, Saukh, Khayrulina), traditional pedagogy insists on regarding it as "the process of transferring experience by one generation to the other and its assimilation by the other generation" (Fitsula 2009: 112-117).

Therefore, since the leading idea of humanization of upbringing is to target its goals, content, forms and methods to facilitating the self-development of personality on the basis of subjective activities of a child, the question arises about forming the upbringing space for free self-determination in the modern educational environment, first of all, with the aim of providing pupils with the required amount of external freedom and, secondly, with effective assistance in the development of internal freedom, freedom of a personality as a prerequisite for self-regulation of behaviour and responsible self-determination in life.

\section{Subjectivity as a quality of a child's personality}

The notion of "subjectivity" (from the Latin noun "subjectum") has become part of the scientific usage in the 80 s of the last century. By the definition of Rom Harré (cf. van Langenhove (ed.) 2010), the subjectivity is the realized ability of people to influence their world and not only recognize it and attribute personal or inter-subjective significance to it. In domestic psychological and pedagogical literature the term "subjectivity" was first used in his studies by Aleksei Leontiev (1975), with this term meaning a certain set of personality qualities that characterize the sphere of its activity abilities. According to $\mathrm{S}$. $\mathrm{Ru}$ binshtein (2003), subjectivity is treated as an ability of a personality to make changes in the world and in itself. This ability is formed in the process of individual development and gaining by a personality such qualities as activism, ability to self-development and integration, self-determination and self-regulation, self-movement and self-improvement. It is due to its own subjective activity a personality acquires the ability to reveal its individuality (Rastrygina 2019).

In the discursive field of modern pedagogical science and, in particular, in the theory of upbringing, the category of subjectivity is defined as an active, purposeful, initiative, creative and constructive position of a personality in everyday life activities. Thus, modern researchers state that "...subjectivity rests on the basis of recognition of the identity 
and intrinsic self-worth of each personality as an individual, endowed with unique natural properties and abilities, subjective social experience and competence, capable of initiative, activities and independence as a subjectively possible basis for human existence" (Khomenko 2013: 16-17). Alla Boyko (2012) justifiably proves that upbringing of a personality is carried out on the basis of subject-to-subject relations, which are determined by knowledge, culture, pedagogically appropriate emotional-volitional sphere and behaviour of, above all, the two main subjects - a teacher and a student, and sees the sense of upbringing in creating conditions for disclosure of natural inclinations of a child, their development and enrichment, which facilitates "self-movement" of a personality. Thus, according to the founder of the national humanistic system of upbringing Evgeniya Bondarevskaya (1999) treating a child as a subject, an individual bearer of a personality activity, and creating conditions for his or her self-development is the main sign of humane, personality-centred education. The nature of interaction between a teacher and a student in the process of education and upbringing determines the ascent of a child's personality to the priorities of his or her own world of values and values of the society, contributes to the acquisition of significant qualities and vital achievements. The effectiveness of this process is reflected in consistent positive changes that occur in the field of communication, activities, behaviour and attitudes of a pupil, which is a pupil's personality growth. Upbringing in this context is carried out as a process of pedagogical assistance to a child in the becoming of his or her subjectivity, cultural identification, socialization, vital selfdetermination, which, in our opinion, requires the creation in modern educational environment an appropriate upbringing space for free self-determination of a personality on the principles of freedom pedagogy as one of the mostly demanded model of upbringing within the frames of the new education paradigm in the 21 st century, that meets the requirements of time and aims at development of subjective activity of a child, his or her self-improvement, self-expression, and self-realization.

\section{Theoretical foundations of the concept of freedom pedagogy}

The socio-philosophical concepts of interconnection of freedom and necessity, freedom as a necessary condition for the development of essential forces of a personality have become the theoretical basis for the development of the concept of freedom pedagogy (Fikhte 1913; Sartr 1990; Abbaniano 1992; Berdyaev 1993; Yaspers 1991 etc.); as well as the theoretical ideas about self-actualization of a personality, its formation as a subject of vital activities (Maslow 1971; Rogers 1983; Abulkhanova-Slavskaya 1991; Ball 2011) and the concepts of humanization of education and upbringing (Bekh 2008; Zyazyun 2000; Rastrygina 2004; Chumak 2017 and others), the relevant analysis of which has also become the basis for rethinking and modern reconstruction of methodological foundations of the theory of free upbringing with the aim of using the ideas and achievements of this trend of humanistic pedagogy in the process of solving the problems of formation of personality freedom of children. It is freedom of a personality that gains particular importance for 
Ukrainian education on the way to the real, not declared realization of the humanistic essence of a new educational paradigm, where ".. each individual becomes the main link. The maximum disclosure of his or her individual abilities, the unique, unrepeatable features of the psyche and the intellect becomes the main purpose of the educational process as a whole" (Khomenko 2013: 18). The establishing of conditions for the development of subjectivity, for the endless process of a man's self-creation, personality functions of a growing person, the support of self-cognition, self-determination and self-realization are the components of this global aim.

In spite of the certain diversity and national originality of humanistic concepts related to a personality freedom, we have identified a number of general ideas of free upbringing which testify to the intrinsic unity of this pedagogical direction. Namely: support on the inner activity of a child, his individual inclinations and capabilities; establishing of external conditions (organization of environment, experience) to stimulate independent development of a child; belief in the possibility of a person to achieve personal freedom and freedom in the society through some organized upbringing; belief in the natural goodness and creative abilities of a child, which is combined with the conviction that any external influence on the creative potential of a child impedes its development; centring of the upbringer's efforts on a child's gaining his or her own experience, on the basis of which there occurs full-fledged development of a personality; encouraging children for having an active attitude to life, culture, educational and cognitive activity and the need for systematic self-education and self-upbringing; the interpretation of the school as a living organism that is constantly evolving in accordance with the nature of a child; understanding of the role of a teacher as a facilitator in organizing the educational and upbringing environment for children to show their creative opportunities; organization of life of the school community on the basis of self-government (Rastrygina 2004: 214-219).

A comparative analysis of the pedagogical ideas of upbringing by freedom shows that the theoretical component of this course was a set of somewhat autonomous concepts combined by an ideological invariant. Each of them was characterized by its peculiarities and different degree of development, but at its core it was based on the fundamental principles of free upbringing.

\section{The invariant principles of freedom pedagogy}

We have named the invariant principles of freedom upbringing the fundamental ideas about the essence and organization of the upbringing process, which are, in one way or another, declared in all directions of free upbringing, regardless of their national, temporal or social specificity. The variability of pedagogical positions of different representatives of free upbringing is manifested in the degree of orientation to one or another principle, and in the methodological ways of their realization. Among these principles we have distinguished the following: the principle of self-esteem of a personality, the principle of the absolute value of childhood, the principle of the nature-appropriate upbringing, the princi- 
ple of freedom and the principle of harmonization of the influence of social environment and of upbringing.

The essence of the principle of self-worth of a personality is in recognition of the following: a child's personality is the initial basis and at the same time the main goal and main result of the process of education and upbringing, which means, the latter is directed towards preserving and developing in a child's mind the child's individual image, providing all the necessary conditions for his or her personal self-realization. It also demands that a tutor should respect any child, whatever he or she is at a given moment of his or her life, with all their merits and disadvantages. A particular personality, a real child is declared as a goal in itself, not a means of achieving any other goal. The aim of the pedagogical process is thought to be inside the child, not beyond. Accordingly, the process of upbringing is aimed at meeting the needs and interests of each child, ensuring each child with the opportunity to implement an individual program of development.

The principle of intrinsic value of childhood affirms the self-sufficient meaning of the children's period of life, emphasizing its originality, imposing a ban on the approach to childhood with utilitarian measures. This principle contrasts with the traditional setting for preparing children for future adulthood. Proponents of free education pointed at the inability to sacrifice childhood for the sake of an indefinite future. Not in preparing children for future life in the traditionally understood sense, but in creating favorable conditions for the developing of all forces of a child's body, they saw the task of the teacher.

The principle of environmental compliancy of upbringing affirms the need to raise a child only in accordance with the known natural patterns of its development and the world of nature as a whole. Thus denying voluntarism and arbitrariness in upbringing, it is emphasized that upbringing as a purposeful process should serve the "interests" of natural development of a child's personality.

The principle of freedom demands to carry out the process of upbringing, avoiding any form of violence against a personality. The very name of free upbringing theory is the evidence of importance of this principle. The basis of free upbringing principle is a special attitude to a child's nature. A child, to the mind of free upbringing theorists, does not carry any inherent moral defects and is perfect in this respect. That is why, the requirement of freedom for maximal implementation of all its inborn qualities is only natural. Any form of violence, any external influence with the aim of forming a certain type of a personality with predetermined traits will lead away from a naturally defined image of a personality. The essence of free upbringing is in the ensuring of conditions for developing a personality's natural qualities and abilities and in recognition of the fact that its individuality can mostly be revealed in the absence of external pressure and restrictions to its expression. However, freedom is not equated with permissiveness. Freedom means ability to go one's own way as far as the laws of the surrounding world, nature, the society, and specific circumstances of life would allow. It is taken for granted that freedom is inextricably tied to responsibility of a personality for its personal choice. 
The principle of harmonization of influences of social environment and upbringing makes adjustments, restricting, in its peculiar ways, the effect of all other principles of free upbringing theory, forcing teachers to reckon with powerful influences of the surrounding society on the development of a child.

The defined principles form an invariant core of freedom pedagogy and constitute a coherent system, the elements of which are closely interrelated. Each of them assumes the presence of the others, contains them in their most effective, interrelated form.

The substantiated principles of free upbringing are the basis for freedom pedagogy as a special trend of humanistic pedagogy, which considers the theoretical and practical foundations of the development of the internal freedom of a personality, his or her subjectivity and ability to make conscious and responsible self-determination, self-selection and realization of his or her own path.

\section{Activation of a child's subjectivity based on the pedagogy of freedom}

From the standpoint of freedom pedagogy, we have rethought the purpose of upbringing, developed the technology of its realization, and defined the requirements for a personality of the teacher, able to work effectively on the principles of upbringing by freedom.

The objective of upbringing in the context of freedom pedagogy is an internally free, ready for the vital self-determination personality, characterized by: a highly developed need for self-actualization, targeted at higher vital values (goodness, truth, justice, beauty, etc.); ability to self-controlled activities and behaviour; the pursuit of competence; realistic and unbiased perception of the world, openness to new experiences and motivation for the search of truth, the ability to take into account different views; positive I-concept; volitional qualities that allow to overcome external and internal obstacles on the way of affirmation of personal values; self-respect in unity with the willingness to respect other people; democratic style of communication; acceptance of socio-cultural norms and simultaneous critical attitude to them, the ability to form one's own "personality norms". From the pedagogical point of view, a personality, possessing all of the mentioned qualities is regarded as an ideal of upbringing, a personality targeted at the values of freedom.

Given the need to identify ways of developing internal freedom of a personality as a basis for the becoming of his or her subjectivity, we consider it necessary to present the pedagogical conditions under which, in our view, we are able to activate the subjective activities of a child. In our mind these conditions are: expanding the boundaries of a child's awareness of his or her physical, mental and spiritual strengths, self-awareness and awareness of the surrounding reality; providing pupils with the "space free from supervision"; creation of situations of uncertainty in the pedagogical process, which encourage pupils to self-determination, independent choice; targeting of the pedagogical process at the development of individual abilities and inclinations of pupils, facilitation of their creative self-realization; maximum enrichment (amplification) of the content, forms and methods of specifically children's activities and communication, realization of potential 
opportunities for development, which get opened in childhood; formation of an emotionally comfortable upbringing environment that stimulates the manifestation of subjective activities of a personality.

Practical implementation of the identified psychological and pedagogical conditions requires a certain design of the corresponding upbringing environment that stimulates manifestation of subjective activities and free self-determination of a personality.

The upbringing space of free self-definition is understood as a specially organized pedagogical environment that provides opportunities for the manifestation of various forms of subjective activities of a personality: initiative, which is manifested in the initiation and deployment of an activity without external prompting; volitional, which provides mobilization of a pupil's resources to overcome objective and subjective obstacles in the way of activities, of which the pupil is conscious; creative, which is revealed in solving problems for which neither ways of solution nor possible results are known in advance; over-situational, that is, activities, going beyond the situational frames, given by the socio-cultural norms or corresponding to former experience of a pupil; self-governing, which manifests itself in a personality's conscious management of his or her capabilities, the construction and implementation of life strategies, the organization of their life path.

In developing the model of the upbringing space of free self-determination of a personality, we relied on the theory of modelling and construction of humanistic upbringing environments, the concept of pedagogical relations and the theory of possibilities by James Gibson (1979). The basic structural units of our modelled upbringing space of free selfdetermination of a personality are the physical environment, socio-psychological factors and the program of upbringing. Accordingly, the structural model of this space contains three basic components: spatial, socio-psychological and organizational-pedagogical.

The educational space, aimed at the development of inner freedom of a personality, should provide opportunities for satisfying the basic needs and realizing personality's values of all subjects of the pedagogical process, above all, pupils. This implies correspondence of the spatial, socio-psychological and organizational-pedagogical components of the upbringing space to the needs and capabilities of children as subjects of the upbringing process. The leading role in the organization of the zone of developing opportunities belongs to the organizational and pedagogical component, which is intended to adequately mediate and appropriately organize the interaction of the subjects of pedagogical process with the subject component and socio-psychological component of the upbringing space. The effective functioning of each of these components is possible only under certain conditions:

- The spatial component: heterogeneity and complexity of the environment; interconnection of functional zones; flexibility and manageability of the environment; individualized environment; authenticity of the environment.

- The socio-psychological component: mutual understanding and satisfaction with the relations of all subjects of the upbringing process; positive-optimistic mood of all its subjects; credibility of teachers; partnership of all subjects in managing the upbringing process; cohesion and consciousness of all subjects. 
- The organizational and pedagogical component: ensuring freedom and the right for a choice in the upbringing process; recognition of self-worth of a child and childhood as a special stage of a human life path; dialogization of the pedagogical space; personalization of pedagogical relations; problematization of the educational process; individualization of educational interaction.

The fundamental condition for a child's personality growth, disclosure of his or her uniqueness and originality, developing of his or her capacity for self-determination and self-regulation is the atmosphere of freedom, which is cultivated in pedagogical environment. Freedom of a child is an important condition for realization of his or her needs and interests, including the need for communication, self-affirmation, testing of one's own strength, creative abilities. Being in an active upbringing environment, in which various opportunities for free choice and expression of subjective activity are created, a personality strives towards those, who at a given moment are the most significant, adequate to its internal tendencies of development. Freedom provides opportunities for creative selfdisclosure, and requires from a personality to correlate his or her needs with the interests and freedom of others, thereby providing conditions for the developing of responsibility and self-regulation, awareness of the relationship with realities of life, legal and moral norms of society.

The effective functioning of the upbringing space of free self-determination of a personality implies a special type of pedagogical activity that supports development of subjective activities of pupils. This, in turn, puts particular demands on pedagogues, who are able to accomplish these tasks. A decisive role is played by their personality and professional attitude, which allows them to work in line with freedom pedagogy. The main components of this attitude are: perception of a child's personality as a value; positive I-concept of a teacher; targeting at the invariant principles of freedom pedagogy.

The forming of a corresponding pedagogical attitude is determined by the three groups of factors: 1) internal, subjective and a personality-related: a teacher's self-awareness, the level of his self-actualization, the adopting of humanistic values, the developed of reflective and projective abilities, motivation, competence, creativity; 2) objective, external factors related to the requirements of professional activity in the context of freedom pedagogy; 3) objective and subjective factors related to the organization of the upbringing environment.

Therefore, the formation of the humanist position of the teacher is conditioned by the dialectic of internal (personal) and external (socio-professional) factors and depends on the teacher's attitude towards the essential characteristics of a humanist-oriented upbringing system. In this case, personal characteristics are the pivotal factor that determines professional position. Today, when humanistic values, although declared by the community, have not yet become dominant; when there are no structures that concentrate in themselves the upbringing culture and are able to transmit it in an open society, and not only in certain educational institutions; when a significant number of school children, students and teachers do not have practical experience of self-realization in the education system 
of a humanistic type, in these circumstances, the objective and subjective factors of organizing a professional environment, managing and training teachers capable of acting on the principles of freedom are given particular weight.

The selected factors are the basis for building a system of training the specialists who are able to work effectively on the principles of freedom pedagogy. This system becomes effective if it is deployed on the basis of innovative content, methods and forms that provide a personality-centred approach and solve two problems: the development of a humanistic position of future professionals and the teaching of practical methods that allow to work in the paradigm of freedom pedagogy.

As mentioned above, freedom pedagogy as one of the trends of humanistic pedagogy develops in line with temporary concepts of humanization of education, which are based on a personality-related approach, the concept of pedagogical support for a personality, the theory of modelling the humanistic upbringing systems, pedagogy of non-violence, etc.

On the basis of comparative analysis of the offered in these concepts ways of defining and means of implementing the upbringing tasks, we have outlined the two main approaches to the organization of the upbringing process, based on the principles of freedom pedagogy: pedagogy of indirect upbringing influence (directed freedom) and pedagogy of assistance (support). Pedagogy of directed freedom regards upbringing as a hidden influence on a personality through the appropriate organization of its substantive and social environment. A personality is given freedom of choice, but through proper organization of the upbringing environment, his or her development is guided in the desired direction. Due to this, pupils develop the ability to live under conditions of freedom, to take responsible decisions, to make independent life choices, despite the fact that their freedom and independence is indirectly programmed and directed by a tutor. Unlike pedagogy of directed freedom, the method of pedagogy of assistance has it, that it is the pupil who defines the upbringing task, and the teacher only assists a child in the process of self-determination and self-realization. Upbringing is interpreted as pedagogical support, providing conditions for self-actualization of a personality, the spontaneous development of his or her inclinations and subjective activities. In such circumstances, a pupil becomes the full partner of a teacher and their relationships become truly subject-subjective.

\section{Conclusions}

In view of the above, we can conclude that an effective factor in intensification the subjective activities of a child is the establishing within the educational environment of an educational institution the upbringing space of free self-determination on the basis of invariant principles of the concept of freedom pedagogy. Regarding the upbringing space of free self-determination as a specially organized pedagogical environment, which contains three basic components and provides opportunities for manifestation of the initiative, volitional, creative, over-situational, self-managerial forms of subjective activities of a child, we propose pedagogical conditions for a child's effective development. It has been found 
that such efficiency is defined by heterogeneity and complexity of the environment, the interconnection of functional zones, the flexibility and controllability of the environment, its individualization and authenticity (spatial component); mutual understanding and satisfaction with the relations of all subjects of the upbringing process, their positively-optimistic mood, credibility of teachers, partnership and participation of all subjects in managing the upbringing process, their cohesion and consciousness (socio-psychological component); ensuring freedom and the right of choice in the upbringing process, recognizing the selfworth of a child and childhood as a special stage of the human life path, dialogization of the pedagogical space, personalization of pedagogical relations, problematization of the educational process, individualization of the upbringing interaction (organizational and pedagogical component). There have been presented basic approaches to the organization of the upbringing process on the principles of freedom pedagogy: pedagogy of indirect upbringing influence (directed freedom) and pedagogy of assistance (support).

\section{References}

Abbaniano N. (1992), Ekzistentsiya kak svoboda. "Voprosy philosofii", 8.

Abulkhanova-Slavskaya K. (1991), Strategiya zhyzni. Moskow, Mysl'.

Ball G. (2011), Osobystist yak modus kultury i yak integratyvnaya kist osoby. "Goryzonty osvity", 3. Berdyaev N. (1993), Subiektivizm i individualizm v obschesvennoi philosofii. Moskow, Uchitel.

Bekh I. (2008), Vyhovannya osobystosti. Pidruchnyk dlya studentiv vyschnavchalnyh zaladiv. Kiev. Boyko A. (2012), Phenomen "subiek-subiekt nividnosyny" - strategiya podalshogo rozvytku pedagogichnoi teotii s practyky. Gumanizatiaya na vchalno-vyhovnogo protsesu. Spetsvypusk 8. Sloviyansks.

Bondarevskaya E. (1999) Pedagogika: lichnoct v gumanno-orientirovannyh teotiyah i sistemah vospitaniya. Rostov na Dony, Utchitel.

Chumak O. (2017), Paradygmaosvity 21th stolittya: innovatsiini aspecty. http://virtkafedra.ucoz.ua/ el_gurnal/pages/vyp7/konf1/Chumak.pdf. date of access 07/31/2020

Fikhte I. (1913), Naznachenie cheloveka. St. Petersburg, Izdanie zhurnala 'Zhizn' dlja vsekh'.

Fitsula M. (2009), Pedagogika. Navchalnui posibnyk. Rosdil Teoriya Vyhovannya. https://academiapc.com.ua/product/73; https://stud.com.ua/61108/pedagogika/teoriya_vihovannya, 7.31.2020.

Gibson J. (1979), The Ecological Approach to Visual Perception. Boston, Houghton Mifflin Harcourt.

Khomenko A. (2013), Subiektnist yak providnyi pryntsyp vykhovannya osobystosti. "Zbirnyk naukovuh prats PNPU imeni V.G. Korolenka. Pedagogichni nauky", 3(59).

Leontiev A. (1975), Activity. Consciousness. Personality. Moscow, Politizdat.

Maslow A. (1971), The farther reaches of human nature. New York, Penguin Books.

Rastrygina A. (2004), Rozvytok teorii vilnogo vykhovahhya y vitchyzhyahii izarubizhnii pedagogitsikintsya $19^{\text {th }}$ - pershoipolovyny $20^{\text {th }}$ stolittya. Dissertation for a scientific degree Doctor of Pedagogical Sciences, Kiev.

Rastrygina A. (2019), Future teacher-musician as a subject of professional and personality development in a university artistic educational space. In: E. Szatan, A. Nowak-Łojewska, A. Komorowska-Zielony (red.), Być nauczycielem, być uczniem w perspektywie jutra. Gdańsk, Wydawnictwo Uniwersytetu Gdańskiego. 
Rogers C. (1983), Freedom to learn for the 80's. Columbus, Charles E. Merrill Publishing Company. Rubinshtein S. (2003), Being and Consciousness. Man and the World. St. Petersburg, Peter.

Sartr Zh.-P. (1990), Ekzistentsializm - eto gumanizm. Moskow, Sumerki bogov.

van Langenhove L. (ed.) (2010), People and Societies: Rom Harré and designing the social sciences. London, Routledge.

Yaspers K. (1991), Smysl i naznachenie istorii. Moskow, Politizdat. Perevod s nemetskogo. Mysliyeli XX v.

Zyazyun I. (2000) Kontseptualni zasady teorii osvity v Ukraini. "Pedagogika i pcyhologiya profesiinoi osvity", 1. 